\title{
Sustainability with
}

\section{endogenous \\ discounting}

JOHN M. HARTWICK

NGO VAN LONG

Allier savoir et décision 
2017s-19

\section{Sustainability with endogenous discounting}

John M. Hartwick, Ngo Van Long

\begin{tabular}{c}
\hline Série Scientifique \\
Scientific Series
\end{tabular}

\section{Montréal \\ Octobre/October 2017}

(C) 2017 John M. Hartwick, Ngo Van Long. Tous droits réservés. All rights reserved. Reproduction partielle permise avec citation du document source, incluant la notice $@$. Short sections may be quoted without explicit permission, if full credit, including (C) notice, is given to the source.

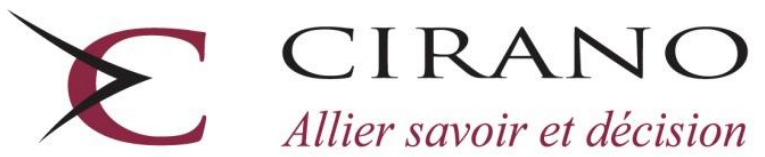

Centre interuniversitaire de recherche en analyse des organisations 


\section{CIRANO}

Le CIRANO est un organisme sans but lucratif constitué en vertu de la Loi des compagnies du Québec. Le financement de son infrastructure et de ses activités de recherche provient des cotisations de ses organisations-membres, d'une subvention d'infrastructure du gouvernement du Québec, de même que des subventions et mandats obtenus par ses équipes de recherche.

CIRANO is a private non-profit organization incorporated under the Quebec Companies Act. Its infrastructure and research activities are funded through fees paid by member organizations, an infrastructure grant from the government of Quebec, and grants and research mandates obtained by its research teams.

\section{Les partenaires du CIRANO}

\section{Partenaires corporatifs}

Autorité des marchés financiers

Banque de développement du Canada

Banque du Canada

Banque Laurentienne du Canada

Banque Nationale du Canada

Bell Canada

BMO Groupe financier

Caisse de dépôt et placement du Québec

Fédération des caisses Desjardins du Québec

Gaz Métro

Hydro-Québec

Innovation, Sciences et Développement économique

Intact

Investissements PSP

Ministère de l'Économie, de la Science et de l'Innovation

Ministère des Finances du Québec

Power Corporation du Canada

Rio Tinto

Ville de Montréal

Partenaires universitaires

École de technologie supérieure (ÉTS)

HEC Montréal

Institut national de la recherche scientifique (INRS)

McGill University

Polytechnique Montréal

Université Concordia

Université de Montréal

Université de Sherbrooke

Université du Québec

Université du Québec à Montréal

Université Laval

Le CIRANO collabore avec de nombreux centres et chaires de recherche universitaires dont on peut consulter la liste sur son site web.

Les cahiers de la série scientifique (CS) visent à rendre accessibles des résultats de recherche effectuée au CIRANO afin de susciter échanges et commentaires. Ces cahiers sont écrits dans le style des publications scientifiques. Les idées et les opinions émises sont sous l'unique responsabilité des auteurs et ne représentent pas nécessairement les positions du CIRANO ou de ses partenaires.

This paper presents research carried out at CIRANO and aims at encouraging discussion and comment. The observations and viewpoints expressed are the sole responsibility of the authors. They do not necessarily represent positions of CIRANO or its partners.

ISSN 2292-0838 (en ligne) 


\title{
Sustainability with endogenous discounting
}

\author{
John M. Hartwick*, Ngo Van Long ${ }^{\dagger}$
}

\begin{abstract}
Résumé/Abstract
We construct a dynamic competitive model with a stock of man-made capital and several stocks of natural resources and ask under what conditions consumption will be constant if infinitesimal households with heterogeneous preferences and endowments discount their utility flows at an endogenous rate that depends some macroeconomic variables. We show that for consumption to be constant, this function must be the marginal product of capital function. We demonstrate that Hartwick's Rule (that along the constant consumption path, resource rents must be invested in man-made capital) holds in a modified form that takes account of natural growth of resource stocks.
\end{abstract}

Mots clés/Key words: Sustainability, Sustainable development, Constant consumption, Hartwick's Rule, Endogenous discounting.

Codes JEL/JEL codes: Q01, Q32

\footnotetext{
*Email: harwick@econ.queensu.ca
}

† Email: ngo.long@ mcgill.ca 


\section{Introduction}

The concern for sustainable development has led to several formulations of the concept of sustainability (e.g. Solow,1974; Pezzey 1992; Cairns and Martinet, 2014; Asheim, 2010; Mitra et al., 2013; Fleurbaey, 2015). The simplest sustainability concept is that of constant consumption. The standard textbook model of the infinitely lived consumer assumes that individuals discount the future at a constant rate, which generically rules out constant consumption over the entire time horizon. There is an alternative stream of literature that assumes endogenous discounting (Uzawa, 1968; Epstein, 1987; Obstfeld, 1990; Pittel, 2002, Ch. 5; Ayong le Kama and Schubert, 2007; Yanase, 2011). For example the discount rate that applies at time $t$ may depend on the consumer's wealth, or consumption level, or the quality of the environment at that time.

In this paper, we suppose that infinitesimal households use an instantaneous discount rate that depends on some macroeconomic variables. We show that for constant consumption to hold, that macroeconomic variables must be such that the endogenous discount rate equals the marginal product of the aggregate capital stock. We demonstrate that under these circumstances, Hartwick's Rule (that along the constant consumption path, resource rents must be invested in man-made capital) holds in a modified form that takes account of natural growth of resource stocks.

\section{The basic model}

There is a continuum of infinitely lived indidividuals (or households), indexed by $\theta$, where $\theta$ ranges from zero to 1 . Their utility functions may differ from each other, and are denoted by $u_{\theta}(c(t, \theta))$ where $t$ denotes time. We assume that $u_{\theta}($.$) is strictly increasing and strictly$ concave, with $u_{\theta}^{\prime}(0)=\infty$. Each individual $\theta$ is endowed with an initial capital stock $k(0, \theta)$ and two (privately owned) resource stocks, $x_{1}(0, \theta)$ and $x_{2}(0, \theta) .{ }^{1}$ For example, $x_{1}$ may

\footnotetext{
${ }^{1}$ Obviously the model can be extended to the case of many stocks of natural resources, and many manmade capital goods.
} 
represent an oil deposit, and $x_{2}$ is a forest. Think of $x_{1}$ as an exhaustible resource and $x_{2}$ as a renewable resource. Let $q_{1}(t, \theta)$ be the individual's extraction from stock $x_{1}(t, \theta)$, say oil, and $q_{2}(t, \theta)$ from stock $x_{2}(t, \theta)$, say timber and firewood. The dynamics of these stocks are

$$
\begin{gathered}
\dot{x}_{1}(t, \theta)=-q_{1}(t, \theta) \\
\dot{x}_{2}(t, \theta)=-q_{2}(t, \theta)+G\left(x_{2}(t, \theta)\right)
\end{gathered}
$$

where $G($.$) is the natural growth function. The individual sells the extracted resources at the$ market prices $p_{1}(t)$ and $p_{2}(t)$. Firms buy these extracted resources and use them as inputs in the production of the final good, which can be consumed or invested. Firms do not own capital: they rent capital from individuals, at the market rental rate $r(t)$. The economy's aggregate capital stock is $K(t)$, where

$$
K(t) \equiv \int_{0}^{1} k(t, \theta) d \theta
$$

Define the aggregate resource inputs by

$$
R_{1}(t) \equiv \int_{0}^{1} q_{1}(t, \theta) d \theta, R_{2}(t) \equiv \int_{0}^{1} q_{2}(t, \theta) d \theta
$$

The aggregate production function is

$$
Y(t)=F\left(K(t), R_{1}(t), R_{2}(t)\right)
$$

where $Y(t)$ is the output of the final good. ${ }^{2}$ The production function has the usual properties: concavity, positive and diminishing marginal products, and the Inada conditions hold. We also assume that $F($.$) is homogeneous of degree 1$, so that firms earn zero profit. Perfect competition prevails, so that

$$
\begin{gathered}
F_{K}\left(K(t), R_{1}(t), R_{2}(t)\right)=r(t) \\
F_{R_{1}}\left(K(t), R_{1}(t), R_{2}(t)\right)=p_{1}(t), \quad F_{R_{2}}\left(K(t), R_{1}(t), R_{2}(t)\right)=p_{2}(t) .
\end{gathered}
$$

\footnotetext{
${ }^{2}$ By having several resource stocks, this production function is slightly more general than the one studied by Solow (1974) and Dasgupta and Heal (1979).
} 
The individual's income at time $t$ is

$$
y(t, \theta)=r(t) k(t, \theta)+p_{1}(t) q_{1}(t, \theta)+p_{2}(t) q_{2}(t, \theta)
$$

Individuals' capital accumulation equation is given by

$$
\dot{k}(t, \theta)=y(t, \theta)-c(t, \theta)
$$

The aggregate resource stocks are

$$
X_{1}(t) \equiv \int_{0}^{1} x_{1}(t, \theta) d \theta, \quad X_{2}(t) \equiv \int_{0}^{1} x_{2}(t, \theta) d \theta
$$

\subsection{Individual optimization}

Each infinitely-lived individual seeks to maximize her discounted stream of utility flow by choosing the consumption path $c(t, \theta)$ and the extraction paths $q_{1}(t, \theta)$ and $q_{2}(t, \theta)$ :

$$
\max \int_{0}^{\infty} u_{\theta}(c(t, \theta)) \beta(t) d t
$$

where $\beta(t) \equiv e^{-\int_{0}^{t} \phi\left(K(\tau), R_{1}(\tau), R_{2}(\tau)\right) d \tau}$ is the discount factor, and $\phi$ is a function of the macroeconomic variables $K, R_{1}$ and $R_{2}$. Since each individual is infinitesimal, her decisions have no impact on the macroeconomic variables. The maximization is subject to the transition equations

$$
\begin{gathered}
\dot{k}(t, \theta)=r(t) k(t, \theta)+p_{1}(t) q_{1}(t, \theta)+p_{2}(t) q_{2}(t, \theta)-c(t, \theta) \\
\dot{x}_{1}(t, \theta)=-q_{1}(t, \theta) \\
\dot{x}_{2}(t, \theta)=-q_{2}(t, \theta)+G\left(x_{2}(t, \theta)\right)
\end{gathered}
$$

and the non-negativity constraints $c(t, \theta) \geq 0, q_{1}(t, \theta) \geq 0, q_{2}(t, \theta) \geq 0$, as well as

$$
\lim _{t \rightarrow \infty} x_{1}(t, \theta) \geq 0, \lim _{t \rightarrow \infty} x_{2}(t, \theta) \geq 0 \text { and } \lim _{t \rightarrow \infty} k(t, \theta) \geq 0 .
$$

In what follows, for notational simplicity, we will suppress the dependence on $t$ and $\theta$ whenever there is no risk of confusion. 
Let $\pi, \psi_{1}$ and $\psi_{2}$ be the co-state variables associated with the state variables $k, x_{1}$ and $x_{2}$. The Hamiltonian function is

$$
H=u_{\theta}(c) \beta+\pi\left[r k+p_{1} q_{1}+p_{2} q_{2}-c\right]-\psi_{1} q_{1}+\psi_{2}\left[G\left(x_{2}\right)-q_{2}\right]
$$

Restricting attention to interior solution for simplicity, we obtain the following optimality conditions

$$
\begin{gathered}
u_{\theta}^{\prime}(c) \beta-\pi=0 \\
\pi p_{1}-\psi_{1}=0 \\
\pi p_{2}-\psi_{2}=0 \\
\dot{\pi}=-\frac{\partial H}{\partial k}=-r \pi \\
\dot{\psi}_{1}=-\frac{\partial H}{\partial x_{1}}=0 \\
\dot{\psi}_{2}=-\frac{\partial H}{\partial x_{2}}=-\psi_{2} G^{\prime}
\end{gathered}
$$

The transversality conditions are

$$
\lim _{t \rightarrow \infty} \pi(t) k(t)=0, \lim _{t \rightarrow \infty} \psi_{1}(t) x_{1}(t)=0, \text { and } \lim _{t \rightarrow \infty} \psi_{2}(t) x_{2}(t)=0
$$

\subsection{The competitive equilibrium}

In this subsection, we make use of the individual optimality conditions and the firms' equilibrium conditions to derive some properties of the competitive equilibrium path of the economy.

Taking the logarithm of equations (3), (4) and (5) we obtain

$$
\begin{gathered}
\ln u_{\theta}^{\prime}-\int_{0}^{t} \phi\left(K(\tau), R_{1}(\tau), R_{2}(\tau)\right) d \tau=\ln \pi \\
\ln \pi+\ln p_{1}=\ln \psi_{1} \\
\ln \pi+\ln p_{2}=\ln \psi_{2}
\end{gathered}
$$


Differentiating equations (10) to (12) with respect to time, and recalling (1) and (2) we get

$$
\begin{gathered}
\frac{u_{\theta}^{\prime \prime}(c(t)) \dot{c}(t, \theta)}{u_{\theta}^{\prime}(c(t))}-\phi\left(K(t), R_{1}(t), R_{2}(t)\right)=r(t)=F_{K} \\
\frac{\dot{\pi}}{\pi}+\frac{\dot{p}_{1}}{p_{1}}=\frac{\dot{\psi}_{1}}{\psi_{1}} \Longrightarrow-r(t)+\frac{1}{F_{R_{1}}} \frac{d}{d t} F_{R_{1}}=0 \\
\frac{\dot{\pi}}{\pi}+\frac{\dot{p}_{2}}{p_{2}}=\frac{\dot{\psi}_{2}}{\psi_{2}} \Longrightarrow-r(t)+\frac{1}{F_{R_{2}}} \frac{d}{d t} F_{R_{2}}=-G^{\prime}\left(x_{2}\right)
\end{gathered}
$$

Equation (13) states that consumption will be constant if and only if the instantaneous discount rate $\phi\left(K(t), R_{1}(t), R_{2}(t)\right)$ is identically equal to the function $F_{K}$. Equation (14) states that the rate of increase in the price of oil must equal the rate of interest (Hotelling's Rule). Equation (15) says that the rate of increase in the price of timber is equal to the excess of the rate of interest over the natural rate of forest reproduction.

Proposition 1: The competitive equilibrium of the economy is characterised by a constant consumption path for all individuals if and only if individuals' endogenous discount function is equal to the marginal product function $F_{K}$.

\section{Net savings rule for constant consumption}

The competitive equilibrium with constant consumption that we described in the preceding section implies that sufficient savings are undertaken to ensure sustainability. What can we say about the aggregate savings of the economy? To answer this question, it is convenient to think of the existence of a social planner that maximizes a constant stream of aggregate consumption. The optimal control problem of the social planner consists of choosing a constant $\bar{C}$ such that solves

$$
\max \bar{C}
$$

subject to

$$
\begin{gathered}
\dot{K}(t)=F\left(K, R_{1}, R_{2}\right)-\bar{C}, K(0)=K_{0}>0 \\
\dot{X}_{1}=-R_{1}, X_{1}(0)=X_{10}>0
\end{gathered}
$$




$$
\dot{X}_{2}=G\left(R_{2}\right)-R_{2}, X_{2}(0)=X_{20}>0
$$

and

$$
\lim _{t \rightarrow \infty} K(t) \geq 0, \lim _{t \rightarrow \infty} X_{1}(t) \geq 0, \lim _{t \rightarrow \infty} X_{2}(t) \geq 0
$$

As shown in Cairns and Long (2006), for this type of problem where the maximand is not an integral, the Hamiltonian function is simply the the sum of stock dynamics weighted by the corresponding co-states, and it takes the value of zero along the optimal path, i.e.,

$$
\pi^{S}(t)\left[F\left(K(t), R_{1}(t), R_{2}(t)\right)-\bar{C}\right]-\psi_{1}^{S}(t) R_{1}(t)+\psi_{2}^{S}(t)\left[G\left(R_{2}(t)\right)-R_{2}(t)\right]=0
$$

where $\pi^{S}, \psi_{1}^{S}$ and $\psi_{2}^{S}$ are the co-state variables in the social planner's optimization problem. Dividing (20) by the shadow price of capital, it follows that the optimal investment in manmade capital must satisfy the condition

$$
I(t) \equiv F\left(K(t), R_{1}(t), R_{2}(t)\right)-\bar{C}=\left\{\frac{\psi_{1}^{S}(t)}{\pi^{S}(t)} R_{1}(t)+\frac{\psi_{2}^{S}(t)}{\pi^{S}(t)} R_{2}(t)\right\}-\frac{\psi_{2}^{S}(t)}{\pi^{S}(t)} G\left(R_{2}(t)\right)
$$

That is, investment in man-made capital must equal the value of the extracted resources (the terms inside the curly brackets) net of the natural growth of the renewable resource, $\frac{\psi_{2}^{S}(t)}{\pi^{S}(t)} G\left(R_{2}(t)\right)$. This is a version of Hartwick's Rule (Hartwick, 1977, Dixit el., 1980). It is also clear that the ratios of the social planner's costate variables in this section correspond to the market prices in the decentralised version that we studied in the preceding section:

$$
\frac{\psi_{1}^{S}(t)}{\pi^{S}(t)}=\frac{\psi_{1}(t, \theta)}{\pi(t, \theta)}=p_{1}=F_{R_{1}}, \frac{\psi_{2}^{S}(t)}{\pi^{S}(t)}=\frac{\psi_{2}(t, \theta)}{\pi(t, \theta)}=p_{2}=F_{R_{2}}
$$

Proposition 2: If individuals use an endogenous discount rate that is equal to the marginal product of capital, then society's consumption path is the highest possible constant consumption path. Along such path, at each point of time, the investment in man-made capital is equal to the value of all extracted resources, net of the value of their natural growth. 


\section{Concluding Remarks}

We have shown that sustainability (in the sense of constant consumption) can be achieved in the market economy if individuals use an endogenous discount function that is equal to the marginal product of capital. The model abstracts from externalities (such as climate change induced by the emissions of GHGs from the burning of fossil fuels and firewood). When there are externalities, the constant consumption path achieved by the unregulated market is socially inefficient. Obviously, social intervention such as the use of a carbon tax would be required to restore efficiency (see e.g. d'Autume et al., 2010)

\section{References}

[1] Asheim, G. B. (2010), Intergenerational Equity, Annual Review of Economics, Vol. 2(1), pp. $197-222$.

[2] Ayong le Kama, A. and K. Schubert (2007), A Note on the Consequences of an Endogenous Discount Depending on the Environmental Quality. Macroeconomic Dynamics, Vol. 11, pp. 272-89.

[3] Cairns, R. D. and N. V. Long (2006), Maximin: A Direct Approach to Sustainability. Environment and Development Economics, Vol. 11(3), pp. 275-300.

[4] Cairns, R. D. and V. Martinet (2014), An Environmental-Economic Measure of Sustainable Development, European Economic Review, Vol. 69(C), pp. 4-17.

[5] d'Autume, Antoine, J. M. Hartwick and Katheline Schubert (2010), The Zero Discounting and Maximin Optimal Paths in a Simple Model of Global Warming. Mathematical Social Sciences, Vol. 59(2), pp. 193-207.

[6] Dasgupta, P. and G. M. Heal (1979), Economic Theory and Exhaustible Resources. Cambridge University Handbooks. 
[7] Dixit, A. K., P. Hammond and M. Hoel (1980), On Hartwick's Rule for Regular Maximin Path of Capital Accumulation and Resource Depletion, Review of Economic Studies, Vol. 47(3), pp. 551-6.

[8] Epstein, L. (1987), A Simple Dynamic General Equilibrium Model. Journal of Economic Theory, vol. 41, pp. 68-95.

[9] Fleuebaey, M. (2015), On Sustainability and Social Welfare, Journal of Environmental Economics and Management, Vol. 71(C), pp. 34-53.

[10] Hartwick, J. M. (1977), Intergenerational Equity and the Investing of Rents from Exhaustible Resources. American Economic Review, Vol. 67(5), pp. 972-974.

[11] Mitra, T., G. Asheim, W. Buchholz, C. Withagen (2013). Characterizing the Sustainability Problem in an Exhaustible Resource Model. Journal of Economic Theory, Vol. 148(5), pp. 2164-82.

[12] Obstfeld, M. (1990), Intertemporal Dependence, Impatience, and Dynamics. Journal of Monetary Economics, Vol. 26(1), pp. 45-75.

[13] Pezzey, John (1992), Sustainability: An Interdisciplinary Guide. Environmental Values, Vol. 1(4), pp 321-62.

[14] Pittel, K. (2002), Sustainability and Endogenous Growth. Edward Elgar, Cheltonmam,

[15] Solow, R. M. (1974), Intergenerational Equity and Exhaustible Resources. Review of Economic Studies, Vol. 41(5), pp. 29-45.

[16] Uzawa, H. (1968), Time Preference, the Consumption Function, and Optimal Assets Holdings, in Wolfe, J. N. (ed.), Value, Capital, and Growth, University of Edinburg Press, pp. 485-504.

[17] Yanase, A. (2011), Impatience, Pollution, and Indeterminacy. Journal of Economic Dynamics and Control, Vol. 35(10), pp. 1789-99. 